\title{
RESPONS PERTUMBUHAN SEEDLING MANGGIS (Garcinia mangostana L.) TERHADAP PENAMBAHAN N6-BENZYLADENIN DAN INDOLE BUTYRIC ACID
}

\author{
Muhammad Rizki Zakaria, Rugayah \& Agus Karyanto \\ Jurusan Agroteknologi, Fakultas Pertanian, Universitas Lampung \\ Jl. Prof. Soemantri Brojonegoro, No. 1 Bandar Lampung 35145 \\ Email: rugayah.1961@fp.unila.ac.id
}

\begin{abstract}
ABSTRAK
Manggis (Garcinia mangostana L.) merupakan salah satu jenis tanaman pohon yang tumbuh di daerah tropis dan memiliki nilai manfaat tinggi. Salah satu upaya penyediaan bibit yang dapat dilakukan dalam meningkatkan jumlah dan kualitas bibit manggis adalah dengan pemberian zat pengatur tumbuh benziladenin (BA) dan indole butyric acid (IBA). Penelitian ini bertujuan untuk menentukan konsentrasi benziladenin terbaik untuk pertumbuhan seedling manggis, pertumbuhan seedling manggis yang paling baik antara yang diaplikasikan IBA 100 ppm dengan yang tanpa diaplikasikan IBA, dan konsentrasi BA terbaik dalam meningkatkan pertumbuhan seedling manggis pada masing-masing pemberian IBA. Penelitian ini dilaksanakan di rumah kaca Hortikultura Fakultas Pertanian Universitas Lampung dari bulan Desember 2015 sampai Maret 2016 dengan menggunakan rancangan acak kelompok (RAK) yang disusun secara faktorial $(3 \times 2)$ dengan tiga ulangan. Faktor pertama yaitu berbagai konsentrasi BA yang terdiri dari: $0 \mathrm{ppm}\left(\mathrm{b}_{0}\right), 20 \mathrm{ppm}\left(\mathrm{b}_{1}\right), 40 \mathrm{ppm}\left(\mathrm{b}_{2}\right)$. Faktor kedua adalah pemberian IBA 100 $\mathrm{ppm}\left(\mathrm{m}_{1}\right)$, dan tanpa IBA $\left(\mathrm{m}_{0}\right)$. Hasil penelitian menunjukkan bahwa pemberian BA dengan konsentrasi $20 \mathrm{ppm}$ menghasilkan pertumbuhan seedling terbaik dibandingkan dengan konsentrasi BA 0 ppm, dan $40 \mathrm{ppm}$. Pemberian IBA dengan konsentrasi $0 \mathrm{ppm}$ dan $100 \mathrm{ppm}$, keduanya tidak menunjukkan perbedaan secara nyata terhadap pertumbuhan tanaman manggis. Konsentrasi benziladenin terbaik bagi pertumbuhan seedling manggis tidak bergantung pada pemberian IBA.
\end{abstract}

Kata kunci: Benziladenin (BA), Indole Butyric Acid (IBA), manggis

\section{PENDAHULUAN}

Manggis (Garcinia mangostana L.) merupakan salah satu jenis tanaman pohon yang tumbuh di daerah tropis dan memiliki nilai manfaat yang tinggi. Buah manggis merupakan sumber serat, vitamin, dan karbohidrat karena mengandung vitamin $\mathrm{A}$, vitamin $\mathrm{C}$, zat besi, kalsium, magnesium, dan potasium yang tinggi, manggis juga mengandung vitamin B kompleks seperti tiamin, niacin, dan asam folat dalam jumlah sedang. Kulit manggis juga mengandung senyawa yang sangat penting yaitu etanol. Menurut Sie (2011), etanol hasil ekstraksi kulit manggis memiliki aktivitas antioksidan yang sangat tinggi. Etanol memiliki beberapa jenis yang terkandung dalam ekstrak manggis, salah satunya adalah xanthones. Kandungan xanthones pada kulit manggis yang menyebabkan warna ungu pada manggis dapat menjadi penangkal kanker (Putra, 2011).

Tanaman manggis merupakan jenis tanaman dengan masa juvenil yang sangat panjang, karena lambatnya pertumbuhan yang disebabkan oleh buruknya sistem perakaran, penyerapan hara dan air lambat, rendahnya laju fotosintesis dan rendahnya laju pembelahan sel pada meristem pucuk (Hernowo, 2011).

Upaya yang dapat dilakukan untuk mengatasi masalah rendahnya pembelahan meristem pucuk adalah dengan pemberian zat pengatur tumbuh (ZPT). Zat pengatur tumbuh adalah senyawa-senyawa yang dalam jumlah kecil dapat mengatur proses pertumbuhan tanaman. Ahli biologi tanaman mengklasifikasikan ZPT ke dalam lima kelompok utama, yaitu auksin, sitokinin, giberelin atau asam giberelat, etilena atau etena, dan asam absisat (Widodo, 2006). Intan (2008) menyatakan bahwa kelompok ZPT yang dapat memacu pembelahan sel dalam jaringan meristematik yaitu dari golongan sitokinin. Sitokinin yang sering digunakan yaitu N6Benziladenin (BA). Fitriyana dkk. (2015) menyatakan bahwa penambahan BA konsentrasi $20 \mathrm{ppm}$ dapat meningkatkan panjang tunas dan jumlah daun pada seedling manggis.

Selain mempercepat pertumbuhan tajuk, pertumbuhan akar juga harus dipercepat karena lambatnya perkembangan akar berdampak pada lambatnya laju pertumbuhan tanaman. Zat pengatur 
tumbuh tanaman yang dpat mempercepat pemanjangan akar yaitu auksin. Riyadi (2011) dalam Fahmi (2013) menyatakan bahwa auksin akan memacu proses terbentuknya akar serta pertumbuhan akar dengan lebih baik. Pernyataan di atas didukung oleh Salim dkk. (2010) yang melaporkan bahwa pemberian indole butyric acid (IBA) $100 \mathrm{ppm}$ memberikan hasil yang terbaik untuk pertumbuhan akar seedling manggis di polibag. Ullah dkk. (2013) menerangkan bahwa pemberian IBA $100 \mathrm{ppm}$ mampu neningkatkan pembesaran akar dan tinggi tajuk pada tanaman mari gold (Tagetes erecta L.). Prastowo dan Roshetko (2006) menyebutkan bahwa konsentrasi auksin yang digunakan pada perendaman setek berkisar antara 5 $100 \mathrm{ppm}$, tergantung jenis tanaman dan jenis auksin yang digunakan.

Pemberian ZPT dengan konsentrasi yang optimal sangat penting untuk mempercepat pertumbuhan tanaman. Jika konsentrasi dinaikkan melebihi batas optimal, maka pertumbuhan tanaman justru akan dihambat dan jika konsentrasi di bawah batas optimal maka ZPT tidak berpengaruh terhadap pertumbuhan tanaman (Abidin, 1994). Dengan menguji beberapa konsentrasi ZPT dalam penelitian diharapkan dapat menentukan konsentrasi ZPT yang optimal bagi pertumbuhan tunas dan akar tanaman manggis. Aplikasi BA dengan konsentrasi yang tepat dan dibarengi dengan aplikasi IBA diharapkan dapat berinteraksi dalam meningkatkan pertumbuhan seedling manggis dan memperbaiki sistem perakaran bibit. Sistem perakaran yang baik akan meningkatkan efisiensi penyerapan hara yang berdampak pada peningkatan laju pertumbuhan bibit manggis.

Penelitian ini bertujuan untuk menentukan konsentrasi benziladenin terbaik untuk pertumbuhan seedling manggis, pertumbuhan seedling manggis yang baik antara yang diaplikasikan IBA 100 ppm dengan yang tanpa diaplikasikan IBA, dan mengetahui konsentrasi BA terbaik dalam meningkatkan pertumbuhan seedling manggis pada masing-masing pemberian IBA.

\section{BAHAN DAN METODE}

Penelitian ini dilaksanakan di rumah kaca Hortikultura Fakultas Pertanian Universitas Lampung pada bulan Desember 2015 hingga Maret 2016. Bahanbahan yang digunakan pada penelitian ini adalah biji manggis, polibag, pasir kali, sekam bakar, bahan organik, tanah, larutan stock BA $1000 \mathrm{ppm}$, larutan stok IBA $1000 \mathrm{ppm}$, fungisida Dithane M-45, akuades, kertas tissue, kertas label, dan air. Alat-alat yang digunakan pada penelitian ini adalah pisau, neraca, cangkul, koret, pinset, mistar, gembor, gelas plastik, botol plastik, spatula, ember, sprayer, kalkulator, kamera, dan alat tulis.

Penelitian menggunakan Rancangan Acak Kelompok yang disusun secara faktorial $(3 \times 2)$ dengan tiga ulangan. Faktor pertama yaitu berbagai konsentrasi Benziladenin (BA) yang terdiri dari: $0 \mathrm{ppm}\left(\mathrm{b}_{0}\right), 20 \mathrm{ppm}$ $\left(b_{1}\right), 40 \mathrm{ppm}\left(\mathrm{b}_{2}\right)$. Faktor kedua adalah pemberian IBA $100 \mathrm{ppm}\left(\mathrm{m}_{1}\right)$, dan tanpa IBA $\left(\mathrm{m}_{0}\right)$. Kombinasi perlakuan berjumlah 6 perlakuan yang diulang sebanyak tiga kali sehingga diperoleh 18 satuan percobaan dan masing-masing perlakuan terdapat 4 sampel. Pengelompokkan didasarkan pada ukuran bibit yang dilihat dari ukuran daun dan jumlah daun serta ukuran tinggi tanaman (kecil, sedang dan besar). Homogenitas ragam diuji dengan uji Bartlet dan aditivitas data diuji dengan uji Tukey. Jika asumsi terpenuhi, data dianalisis dengan sidik ragam, perbedaan nilai tengah perlakuan diuji dengan uji Beda Nyata Terkecil (BNT) pada taraf $5 \%$. Penelitian ini dilakukan melalui beberapa tahapan, yaitu:

(1) Persiapan media dalam polibag

Polibag yang digunakan yaitu dengan ukuran 20 x 35 atau lebih besar dari polibag awal yang digunakan. Media tanam yang digunakan berupa campuran tanah podsolik merah kuning, pupuk kandang kotoran sapi, dan sekam mentah dengan perbandingan 2:2:1 berdasarkaan volume.

\section{(2) Pindah tanam manggis}

Bibit manggis yang digunakan yaitu berumur 6 bulan setelah tanam. Pindah tanam manggis dilakukan dengan memindahkan bibit manggis ke polibag yang lebih besar. Media tanam yang terdapat pada polibag lama tetap digunakan, namun ditambahkan dengan media baru yang telah disiapkan. Pindah tanam manggis dilakukan dengan hati-hati. Polibag lama dipotong dengan menggunakan silet atau cutter dan dilepas dari media tanam manggis. Pelepasan polibag dilakukan dengan hati-hati agar media tanam lama tidak pecah. Disiapkan polibag yang lebih besar, kemudian diisi dengan media baru kurang lebih sepertiga bagian. Media lama dimasukkan beserta manggis ke dalam polibag baru, kemudian diisi dengan media baru hingga penuh dan disiram.

Penyiraman dilakukan secara rutin karena tanaman manggis yang baru pindah tanam rentan terhadap kekeringan akibat stres. Penyemprotan fungisida dilakukan menggunakan Dithane M-45 untuk mencegah tumbuhnya jamur. Setelah dilakukan pindah tanam, polibag diberi label perlakuan dan kelompok. Pengaplikasian perlakuan dilakukan setelah manggis 
sudah tidak stres lagi yaitu kurang lebih 1 bulan setelah pindah tanam.

\section{(3) Perlakuan}

a. Pembuatan larutan stok dan pemberian benziladenin (BA)

Pembuatan larutan stok BA 1000 ppm yaitu dengan menimbang BA sebanyak 1 gram. Diteteskan sedikit demi sedikit $\mathrm{HCl} 1 \mathrm{~N}$ sebanyak $30 \mathrm{ml}$ sambil dikocok hingga BA larut, apabila belum larut bisa ditambahkan beberapa tetes $\mathrm{HCl}$ hingga BA larut. Kemudian dilakukan penambahan akuades dan ditera hingga volume akhir $1000 \mathrm{ml}$. Pada tahap akhir pH larutan dipertahankan menjadi 5,6 menggunakan $\mathrm{PH}$ meter. Apabila pH kurang dari 5,6 maka ditambahkan $\mathrm{KOH}$, dan apabila $\mathrm{pH}$ lebih dari 5,6 maka ditambahkan $\mathrm{HCl}$ hingga $\mathrm{pH}$ menjadi 5,6.

Pemberian BA dilakukan dengan cara penyemprotan pada daun. Volume semprot yang digunakan sebanyak $10 \mathrm{ml} /$ tanaman yang diberikan 3 kali yaitu setiap 10 hari sekali selama 1 bulan. Pemberian BA dilakukan sesuai dengan konsentrasi yang ditetapkan yaitu 0 ppm, 20 ppm, dan 40 ppm.

\section{b. Pembuatan larutan stok dan pemberian Indole Butyric Acid}

Pembuatan larutan stok IBA 1000 ppm yaitu dengan menimbang IBA sebanyak 1 gram. Diteteskan sedikit demi sedikit $\mathrm{KOH} 1 \mathrm{~N}$ sebanyak $30 \mathrm{ml}$ sambil dikocok hingga IBA larut hingga larut, apabila belum larut bisa ditambahkan beberapa tetes $\mathrm{KOH}$ hingga IBA larut. Kemudian dilakukan penambahan akuades dan ditera hingga volume akhir $1000 \mathrm{ml}$. Pada tahap akhir $\mathrm{pH}$ larutan dipertahankan menjadi 5,6 menggunakan $\mathrm{pH}$ meter. Apabila pH kurang dari 5,6 maka ditambahkan $\mathrm{KOH}$, dan apabila $\mathrm{pH}$ lebih dari 5,6 maka ditambahkan $\mathrm{HCl}$ hingga $\mathrm{pH}$ menjadi 5,6.

Pemberian IBA dilakukan dengan cara penyiraman pada bagian pangkal batang. Volume siram yang digunakan sebanyak $15 \mathrm{ml} /$ tanaman yang diberikan 3 kali yaitu setiap 10 hari sekali selama 1 bulan. Pemberian IBA dilakukan sesuai dengan konsentrasi yang ditetapkan yaitu 0 ppm dan 100 ppm.

\section{(4) Perawatan tanaman}

Kegiatan perawatan yang dilakukan meliputi penyiraman dan sanitasi. Penyiraman dilakukan setiap hari dengan menggunakan gembor kecil dan disesuaikan dengan kondisi lingkungan. Penyiraman dilakukan secara teratur, karena tanaman manggis sangat rentan terhadap kekeringan. Sanitasi dilakukan dengan cara membersihkan media semai serta lingkungan untuk mencegah keberadaan hama dan patogen.

\section{(5) Pengamatan}

Variabel yang diamati dalam penelitian ini meliputi tinggi batang, panjang daun, lebar daun, jumlah daun, visualisasi akar dan diameter batang. Selain visualisasi akar, pengukuran semua variabel pengamatan dilakukan dua kali, data awal diukur seminggu sebelum aplikasi pada saat pindah tanam dan pengukuran kedua dilakukan pada akhir penelitian yaitu tiga bulan setelah aplikasi.

\section{HASIL DAN PEMBAHASAN}

Hasil penelitian menunjukkan bahwa pemberian benziladenin meningkatkan pertumbuhan manggis, yang ditunjukkan oleh adanya penambahan panjang daun. Pengaplikasian BA konsentrasi 20 ppm memberikan pengaruh yang lebih baik dibandingkan BA dengan konsentrasi 0 ppm dan 40 ppm yang ditunjukkan dengan penambahan panjang daun (Gambar 1). Hal ini terjadi diduga karena 20 ppm BA merupakan konsentrasi yang dibutuhkan tanaman manggis untuk tumbuh dengan baik. Menurut Fitriyana (2008), pemberian BA 20 ppm memberikan respons pertumbuhan seedling manggis terbaik dibandingkan konsentrasi lain yang diujikan. Kemudian menurut Intan (2008), pemberian BA yang tepat mampu mendorong pertumbuhan tunas samping, dominasi apikal dan perluasan daun.

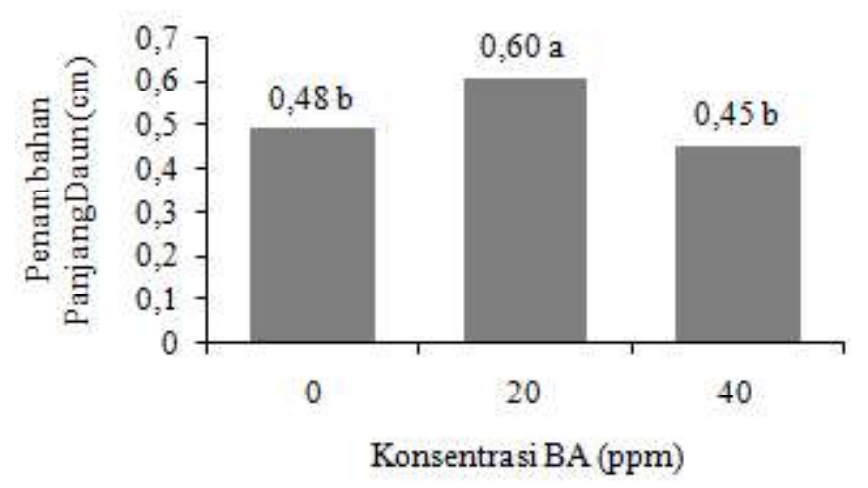

Gambar 1. Pengaruh pemberian benziladenin pada panjang daun manggis. Dua nilai tengah yang diikutu huruf yang sama dinyatakan tidak berbeda nyata pada uji BNT. BNT $0,05=0,086$.

Pengaplikasian benziladenin dengan konsentrasi 20 ppm juga menunjukkan peningkatan diameter batang (Gambar 2). Moncalean dkk. (2001) menyatakan bahwa peningkatan pemberian BA (sitokinin) pada tanaman Actinidia deliciosa dapat mengurangi panjang tajuk. Secara umum, sitokinin berfungsi mempengaruhi pembelahan dan pembesaran sel ke arah samping atau 
dengan kata lain yaitu pembesaran diameter batang sehingga menghambat panjang tunas pada manggis.

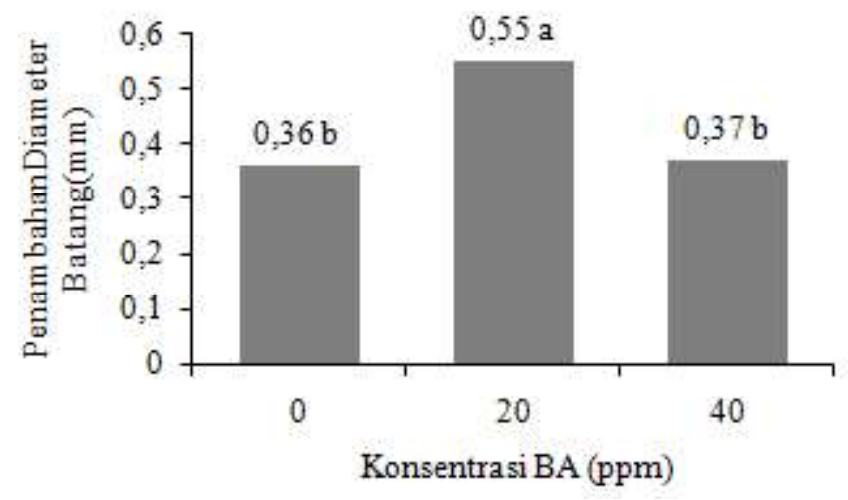

Gambar 2. Pengaruh pemberian benziladenin pada diameter batang manggis. Dua nilai tengah yang diikuti huruf yang sama dinyatakan tidak berbeda nyata pada uji BNT. BNT $0,05=0,019$.

Perlakuan IBA tidak berpengaruh pada semua variabel pengamatan yang telah dilakukan, diduga dipengaruhi oleh beberapa faktor. Manggis yang digunakan sebagai bahan tanam berusia 6 bulan, kemudian dilalukan pindah tanam ke media yang lebih besar. Pada saat pindah tanam ada kemungkinan terjadinya luka pada akar. Akar pada tanaman manggis sangat sensitif, sehingga luka pada akar dapat menyebabkan tanaman menjadi stres dan menghambat pertumbuhan manggis. Akar yang putus juga dapat menghambat pertumbuhan manggis, karena proses regenarasi manggis sangat lambat. Tanaman manggis tidak akan tumbuh sebelum luka pada bagian akar sembuh dan tumbuh akar baru.

IBA memiliki sifat penyebaran yang kecil, artinya IBA hanya akan memberikan respons fisiologi pada tempat dimana IBA diberikan. Hal ini sesuai dengan pendapat (Salim dkk., 2010) yang menyatakan bahwa IBA memiliki sifat penyebaran yang sangat kecil, sehingga apabila IBA diberikan pada akar, ia hanya akan menstimulasi pada bagian akar saja, dan kemungkinan kecil untuk mampu menstimulasi pertumbuhan pada bagian atas tanaman.

Pada kadar rendah hormon atau zat pengatur tumbuh akan mendorong pertumbuhan, sedangkan pada kadar yang lebih tinggi akan menghambat pertumbuhan, meracuni bahkan mematikan tanaman (Supriyanto dan Prakasa, 2011). Konsentrasi IBA 100 ppm dapat dinilai kurang atau melebihi kebutuhan tanaman manggis, sehingga tidak berpengaruh pada pertumbuhan akar manggis. Joni (2015) melaporkan bahwa IBA dengan konsentrasi 200 ppm mampu meningkatkan panjang akar primer dan jumlah akar sekunder dibandingkan dengan perlakuan lainnya.

Pada visualisasi akar manggis dapat dilihat bahwa hampir keseluruhan pertumbuhan akar tanpa aplikasi IBA tumbuh lebih subur dibandingkan dengan aplikasi IBA 100 ppm (Gambar 3).
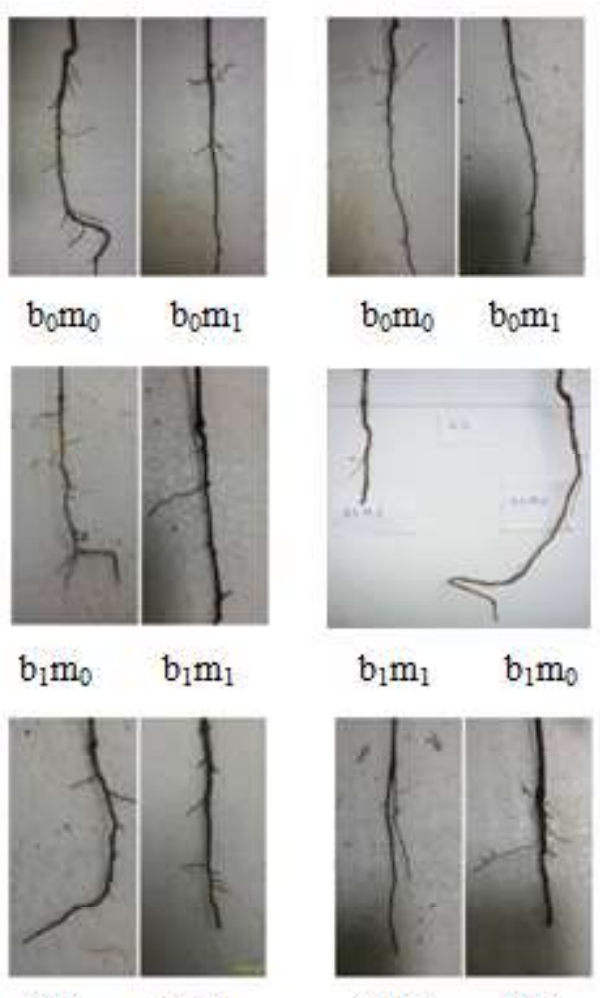

$b_{2} m_{0} \quad b_{2} m_{1}$

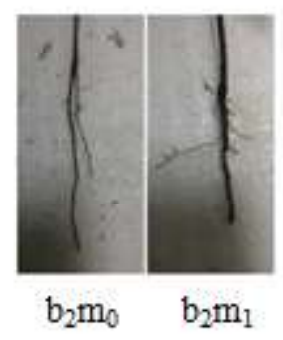

Gambar 3. Penampakkan akar pada perlakuan antara pemberian IBA $100 \mathrm{ppm}\left(\mathrm{m}_{1}\right)$ dan tanpa IBA $\left(\mathrm{m}_{0}\right) \cdot \mathrm{b}_{0}=$ pengaplikasian BA $0 \mathrm{ppm}, \mathrm{b}_{1}=$ pengaplikasian BA $20 \mathrm{ppm}$, dan $\mathrm{b}_{2}=$ pengaplikasian BA $40 \mathrm{ppm}$.

Pada visualisasi akar manggis dapat dilihat bahwa hampir keseluruhan pertumbuhan akar tanpa aplikasi IBA tumbuh lebih subur dibandingkan dengan aplikasi IBA $100 \mathrm{ppm}$. Penghambatan pertumbuhan akar ini kemungkinan terjadi karena konsentrasi IBA 100 ppm yang digunakan dianggap kurang tepat sehingga menyebabkan kurang berkembangnya akar. Menurut Ashari (2006), hormon tumbuh adalah senyawa organik non hara yang disintesis pada salah satu bagian tanaman yang pada konsentrasi rendah mampu menimbulkan respons fisiologis (menmpercepat atau menghambat 
pertumbuhan). Faktor lain yang dapat menghambat pertumbuhan akar yang diaplikasikan IBA yaitu kecilnya volume IBA yang diaplikasikan pada akar, sehingga IBA tidak dipastikan berkontak langsung secara keseluruhan dengan akar.

\section{KESIMPULAN}

Kesimpulan penelitian ini yaitu pemberian benzyladenin dengan konsentrasi $20 \mathrm{ppm}$ mampu meningkatkan pertumbuhan tanaman manggis yang ditandai dengan penambahan diameter batang dan panjang daun. Selain itu, pemberian indole butyric acid dengan konsentrasi 0 ppm dan 100 ppm, keduanya tidak berpengaruh secara nyata terhadap pertumbuhan tanaman manggis. Konsentrasi benzyladenin terbaik bagi pertumbuhan seedling manggis tidak bergantung pada pemberian indole butyric acid.

\section{DAFTAR PUSTAKA}

Abidin, Z. 1994. Dasar-Dasar Pengetahuan tentang Zat Pengatur Tumbuh. Penerbit Angkasa. Bandung.

Ashari, Sumeru. 2006. Hortikultura Aspek Budidaya. UI-Press. Jakarta.

Fahmi, Z. Ismail. 2013. Kajian Pengaruh Pemberian Sitokinin terhadap Pertumbuhan Tanaman. Balai Besar Perbenihan dan Proteksi Tanaman Perkebunan. Surabaya

Fitriyana, F. Asih. 2008. Pengaruh Konsentrasi Benziladenin dan Pembelahan Biji terhadap Pertumbuhan Seedling Manggis (Garcinia mangostana L.). Skripsi. Universitas Lampung.

Hernowo, B. 2011. Panduan Sukses Bertanam 20 Buah dan Sayuran. Agromedia. Jakarta

Intan, R, D, A. 2008. Peranan dan Fungsi Fitohormon bagi Pertumbuhan Tanaman. Makalah Pribadi. Fakultas Pertanian Universitas Pajajaran. Bandung.
Joni, Y.Z., D. Efendi, dan I. Roostika. 2015. Induksi Perakaran Manggis (Garcinia mangostana L.) Secara In Vitro dan Ex Vitro. J. Hort. Vol. 25 (2): 97-105.

Moncalean, P., A. Rodriguez, dan B. Fernandez. 2001. In Vitro response of Actinidia deliciosa Explants different BA Incubatiion Periods. Plant Cell. Tissue and Organ Culture. Vol. 67(3): 257-266.

Putra, S.R. 2011. Manggis Pembasmi Kanker. Penerbit DIVA Press.

Prastowo, N. dan J.M. Roshetko. 2006. Teknik Pembibitan dan Perbanyakan Vegetatif Tanaman Buah. World Agroforestry Center. Bogor.

Salim, H., N. Myrna E.F., Y. Alia. 2010. Pertumbuhan bibit manggis asal seedling (Garcinia mangostana L.) pada berbagai konsentrasi IBA. Jurnal Penelitian Universitas Jambi Seri Sains. Vol. 12(2): 19-24.

Sie, J. O. 2011. Daya Antioksidan Ekstrak Etanol Kulit Buah Manggis (Garcinia mangostana Linn.). Jurnal Ilmiah Mahasiswa Universitas Surabaya. Vol. 2(1): 8-9.

Supriyanto dan K. E. Prakarsa. 2011. Pengaruh Zat Pengatur Tumbuh Rootone-F terhadap Pertumbuhan Stek Duabanga mollucana Blume. Jurnal Silvikultur Tropika. Vol. 3(1): 59-65.

Ullah, Z., S.J. Abbas, N. Naeem, G. Lutfullah, T. Malik, M.A.U. Khan, dan I. Khan. 2013. Effect of indole butyric acid (IBA) and naphthalene acetic acid (NAA) plant growth regulaters on Marygold (Tagetes erecta L.). African Journal of Agricultural Research. 8(29): 4015-4019.

Widodo. A. S. 2006. Peranan Zat Pengatur Tumbuh (ZPT) dalam Pertumbuhan dan Perkembangan Tumbuhan. Available online at: http:// blog.360.yahoo/blog/slideshow.html, [13 Desember 2016]. 